\title{
Towards the possible integration of Psychology and Christian faith: Faculties of human personality and the Lordship of Christ
}

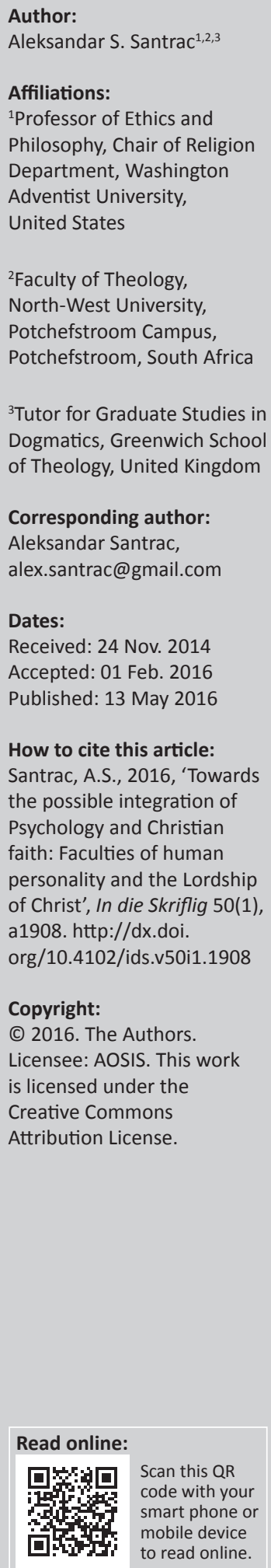

In recent debates every attempt to integrate Psychology and Christian Theology has met with almost complete distrust. This article suggests a possible mode of integration on the basis of the interconnectedness between the faculties of human personality and the idea of the Lordship of Christ. The compartmentalisation of human personality should be resisted, because every human faculty functions holistically. In the biblical revelation each of these faculties is subject to the Lordship of Christ in order to function properly as part of the holistic picture of the imago Dei.

\section{Introduction}

An attempt to integrate Psychology and Christian faith (Theology) is a daunting task because of the divergent approaches of these academic disciplines. Alan C. Tjeltveit, in his article, 'Lost opportunities, partial successes, and key questions: Some historical lessons' (2012), published in the recent volume of the Journal of Psychology and Theology commemorating 40 years of exploring the interrelationships of these two academic disciplines, argues:

The hard questions that arise when we take both psychology and Christian faith very seriously need to be faced, especially those arising in areas in which they conflict and overlap. And we need to be aware of psychologists' underlying assumptions, including ethical and metaphysical assumptions, critiquing those assumptions and thinking through how psychology might be envisioned, not with different data, but with different interpretations and definitions of data, interpretations that are at once consistent with data and with Christian understandings. (p. 20; [author's own emphasis])

This perceptive comment on the processes of interrelating Psychology and Christian faith has similarities to my philosophical arguments presented at the fourth Mind of Christ Conference at the University of the Southern Caribbean (Santrac 2011).

As a professional philosopher and theologian (probably without intention to obtain my third $\mathrm{PhD}$ in the field of Psychology) I am very pleased that the experts in the field like Tjeltveit, who is very appreciative of attempts to integrate Psychology and Christianity, have acknowledged the value of the philosophical understanding of assumptions about worldviews. Some of them even stress that different 'psychologies' are only diverse 'philosophies of life' (cf. Roberts 2012:40). My argument is based on the fact that every theory in Psychology has its philosophical assumptions, both epistemological and metaphysical. I argued (Santrac 2011) that one needs to identify these underlying epistemological and metaphysical presuppositions of both Psychology and Christian faith, and make an attempt to bridge the gap between Psychology and Theology by developing an integrated set of assumptions that will serve as an ideological foundation for academic curricula in Christian Psychology. The task does not seem as implausible as it looked when this idea was formulated, and it is still very promising.

\section{Shifting gears: Towards a new type of integration}

Nevertheless, Stephen C. Evans, a philosopher of religion from Baylor University, seems to be disloyal to a philosophical project of integration, and to undermine even the possibility of integrating psychology and Christian faith (cf. also Shults's (2012:22) critique of Christian Psychology as a discipline). In his article, Doing Psychology as a Christian: A plea for wholeness (2012:33), Evans sides with critics of integration and contends that the essentially secular discipline of Psychology, with its own methods and achievements, and Christianity, with its beliefs expressed in theology, are not easily integrated.

Note: This article partially resembles my paper presented at the Mind of Christ Conference, 19-21 February 2013, Northern Caribbean University, Jamaica. 
In his view, the primary task of the Christian psychologists is not to search for modes of integration of psychology and faith (i.e. to be different from their secular colleagues), but to remain faithful (Evans 2012:34). This vocation is based on implicit Christian scholarship, where the psychologists do allow Christian convictions to shape their work; but this shaping is not so easily recognisable as in explicit Christian scholarship (2012:35). His methodological doubts about integration have led me to shift the emphasis of my research. The focal point of Evans' (2012) commentary that will serve as a foundational principle for further investigation of the matter is the following:

The word integration is closely related to terms such as integral and integrity, and all of these terms are connected to the idea of wholeness or unity. I think the contrast term to integration in the scholarly life is compartmentalization. To be committed to the integration of faith and learning is to be committed to wholeness in one's life as a Christian. The kind of wholeness I have in mind is that in which Christ is seen as Lord of every dimension of one's life. Christian existence is not simply something that pertains to the spiritual or something that is linked to the church or what happens on Sundays. Each of us who names the name of Christ is called by Christ to follow him in every dimension of life. For those who are called to be scholars, this includes the scholarly life, just as those called to be plumbers or dentists should think of their work as part of their calling as Christian disciples. So the primary thing to be integrated is my life as a Christian, not such things as the disciplines of psychology and theology. I am called to bring every dimension of my life under the Lordship of Christ and ask what being a faithful follower of Jesus means for me in each dimension of my existence. If we think of the Christian life as Paul did as one that is lived through faith (the just shall live by faith), then we can say that one part of the task of seeking wholeness is to understand what my faith means for my life as a scholar. It is, I hope, obvious that the task of living authentically as a Christ-follower will be far larger than what one does as a scholar. We are also called to live faithfully as husbands and wives, friends and citizens, members of local communities and local church communities. However, especially in an academic discipline such as psychology, being a representative of Christ's body in the academic world will surely be an important part of one's Christian calling. It is also worth noting that the task of integration as here conceived is just as relevant to theology as it is to psychology. Insofar as theology is an academic field, theologians are also faced with the task of doing their work as theologians in a way that is faithful to their calling as Christ followers. (p. 33; [author's own emphasis])

According to this mode of 'integration', Christ is seen, therefore, as an integral part of every dimension of our lives. In psychological terms, one might argue that the Lordship of Christ should be the living spiritual principle or power controlling every aspect of our personality. Within the realm of Psychology as a science, there are some voices who call for a new understanding of the theory of personality based not only on human intellect and emotion, but also on the ethical and spiritual aspects (Tjeltveit 2012:19). In this regard, Tjeltveit argues that the secular discipline of psychology fails to recognise the unity of personality or the wholeness of the human being (ibid). In contrast to modern psychologists who tend to be more comfortable with the fragmentation and complexity of human nature that is adaptable to multiple contexts in which people operate, modern Theology emphasises the natural unity of personality (Watts 2012:46). This is not a foreign idea in biblical or Christian tradition. In the interests of integrating Psychology and Christian faith, one should strive to create a comprehensive psychological understanding of personality that ought to include explanations on how Theology and Psychology fit together.

Therefore, this article is based on two fundamental assumptions. First, integration of Psychology and Christian faith should not be regarded as an impossible task, though it is very much doubted today. As an academic person and a person of faith I attempt to engage in this process of integration with a certain degree of risk, of course. The risk is real since only a few scholars have thorough academic knowledge of both Psychology and Theology and have read widely in both fields, not to speak about attempts to integrate them.

The problem of integration is this: To integrate Christianity with Psychology one has to convert or reduce biblical wisdom (mind of Christ) to Theology, or a theory about the basis and purpose of living. But the Bible does not address the head, but the heart. The meaning of my walk with God is not a theory. It is the content of worldview and heart commitment of what or Who I live my life out of and unto (i.e. direction). Psychology (theory of personality), in this regard, would be viewed as a comparable worldview (only as a matter of direction) so there would be some hope in the integration model.

On the other hand, if biblical worldview is interpreted as a theoretical construction (i.e. structure) and compared with the theoretical expression of psychological views of personality (i.e. structure), again some forms of integration would be possible. This article made an attempt to follow this form of integration.

There is, of course, considerable risk, as I have already mentioned, to confuse the direction with the structure, namely to integrate biblical convictions of the heart or faith (direction) with theoretical Psychology (the structure of personality), or to integrate biblical theoretical theological construction (structure) with solely individual impressions or preferences of one views of the structure of personality (direction).

In spite of these obvious risks, I still believe in this 'integrative' work because exploring different intersections between faith and any type of learning, and experimenting with integrative processes of this kind, are not foreign to the academic community, and I believe it is desirable. Finally, my academic approach in this article will be based on my Christian convictions, and will therefore represent one of the attempts of integration of Christianity (as Theology) and Psychology (theory of personality) unavoidably from the Christian point of view. 
The second assumption arises from my theological vantage point: I presuppose the validity and authenticity of the Christian faith revealed in the Holy Scriptures. Assuming that the Bible is an authoritative revelation of the Word of God, I will attempt to create a theoretical and theological basis drawn from the Scriptures that might inform and support an integration of Theology with Psychology.

The overarching argument of this research is that each dimension of human existence and personality should be under the control of the Lordship of Christ as presented in the Holy Scriptures. From the psychological standpoint, there are at least five faculties of personality, which might be collectively used as a reference point here for discussion on Christ's Lordship over the comprehensive personality: knowing, feeling, will, conscience, and faith or spirituality (Norlie quoted in Tjeltveit 2012:18). In an integrated 'biblical or Christian psychology' one may therefore speak about Christ's Lordship over intellectual, emotional, volitional, moral or ethical, and spiritual aspects of human personality. Lord is one of the messianic titles given to Christ as an expression of his absolute dominion and loving demands for obedience. In this article recognition of the Lordship of Christ leads to holistic and comprehensive submission of all human faculties.

In the following sections I will be building my case on Evans' recognition of the relationship between the notion of the Lordship of Christ and the faculties of human personality. In addition, by using the methodological approach of Cambridge professor Fraser Watts', Doing Theology in dialogue with Psychology (2012:45-50), this article might open some new vistas for analysis of each of the faculties. In his conclusion, Watts (2012:49) claims that 'a dialogue between theology and psychology can help to hold together the objective and subjective aspects of Christian thought and belief' (author's own italics). The objective theological concept of the Lordship of Christ, revealed incompletely in nature and fully in the Holy Scriptures, will be correlated to the subjective psychological experiences of different faculties of human personality. My investigation will explore Christ's Lordship with regard to different faculties of human personality via the existing revelation of Holy Scripture, together with insights from traditional Christian 'holistic' or 'comprehensive' understandings of human nature, and some discernments of contemporary scholarship. This might result in a modest contribution towards the integration of Psychology and Christian faith.

\section{Integration of the faculties of human personality and the concept of Christ's Lordship Intellect and Christ: The mind of Christ}

William James the pragmatist, philosopher and psychologist of religion, claimed that 'psychology is the scientific study of mental life' (James, quoted in Stevenson \& Haberman 1998:228).
This is a broad and vague definition that encompasses many different approaches to the study of the human being. One of these approaches is based on the nature and development of cognitive structures and processes (1998). However, in order to simplify the terminology, the expression mind will be used here, as it is a term common to Psychology, Philosophy (philosophy of mind) and Christian faith. Furthermore, the psychology of mind includes both the conscious and the unconscious mental state (Freud), though the idea of the unconscious mind was heavily criticised by some philosophers like Jean-Paul Sartre. Sartre (1998:176) asserted that all consciousness is the consciousness of the world (it has a definite object) and therefore the unconscious does not really exist because consciousness is always transparent to itself. Mind therefore encompasses all mental activities like memory, intelligence, thinking, and other states of mind.

However, according to the Christian reformed interpretation of the mind, this faculty is hostile to God because of its carnal nature. The reformers' doctrine of 'total depravity' emphasised that the human mind is alienated from God (Col 1:21, NIV). Scripture reveals that the natural human mind is unspiritual; it is obsessed by earthly things only (Phlp 3:19; Col 2:18). The natural mind is governed by the depraved human nature, 'imagines confusing things' (Pr 23:33) and is 'hostile to God' ( $R m$ 8:7). So the key question is: How can this mind be subject to the Lordship of Christ (the spiritual power outside of its natural realm and function)?

The process of transformation from the natural to the spiritual mind does not happen instantaneously. ${ }^{1}$ The process is governed by the Spirit ( $\mathrm{Rm} \mathrm{8:6),} \mathrm{and} \mathrm{the} \mathrm{natural} \mathrm{processes}$ of thinking, memory, intelligence and conscious or unconscious decisions are 'made new in the attitude of your mind' (Eph 4:23). The 'mindset' of Christ is gradually adopted as a way of life (Phlp 2:5). With a 'wholehearted devotion and with a willing mind' (1 Chr 28:9) ready to fix God's words in the mind (Dt 11:18), persons come into the realm of the Spirit by loving Christ with all of their minds (Mt 22:37) - a mind that is sober because the end of all things is near (1 Pt 4:7). Finally, disciples who understand the nature and the value of Christ's call to the renewal of the mind identify themselves with 'the mind of Christ' (1 Cor 2:16). The mind of Christ is defined here as the ultimate realisation of the complete spiritual amalgamation of the intellectual (and other) faculties of human personality with the divine-human Mind or Spirit of the Lord Jesus Christ. By this unique transcendental experience, the intellect has not been sacrificed but renewed and transformed.

Oswald Chambers, in his book, My utmost for his Highest (2012), explains this total Lordship of Christ over the (conscious) mind that controls the whole nature of a person, even the unconscious:

\footnotetext{
1.The Apostle Paul explains: Therefore, I urge you, brothers and sisters, in view of God's mercy, to offer your bodies as a living sacrifice, holy and pleasing to Godthis is your true and proper worship. Do not conform to the pattern of this world, but be transformed by the renewing of your mind. Then you will be able to test and approve what God's will is - his good, pleasing and perfect will. (Rm 12:1-2)
} 
Have we come to realize that our 'body is the temple of the Holy Spirit'? If so we must be careful to keep it undefiled for Him. We have to remember that our conscious life, even though only a small part of our total person, is to be regarded by us as a 'temple of the Holy Spirit'. He will be responsible for the unconscious part which we don't know, but we must pay careful attention to and guard the conscious part for which we are responsible. (author's own emphasis)

In his somewhat Freudian inclination, Chambers (2012) advocates the Christian attitude of total commitment of the (conscious) mind to the Maker in order to experience the spiritual submission of every dimension of human personality (including the unconscious) to Christ. The mind in its totality and wholeness has to be subjected to the spiritual power of the Son of God.

Therefore, what James (2002:108) called the 'mind-cure movement' or 'New Thought' movement in the second half of the nineteenth century, with its techniques based on popular optimistic science and the evolutionary worldview, seemed to be helpless in the achievement of a total transformation of the human mind. Relatively recent debates on evolutionary psychology, exploring evolutionary processes of survival and how these processes create human behaviour and the function of the human mind (Buss 2011), still, I believe, leave different human faculties, including the human mind, compartmentalised, unintegrated, and alienated from the holistic purpose and function of the human being. Christian faith offers not just a complementary spiritual manual of mind-cure (in response to James), but the unique and indispensable holistic healing of the mind and its full transformation to the original purpose of the creation (in response to Buss). Reason (mind) functions properly, purposefully and holistically only through openness to God in faith. According to Hasel (1993:185), an Austrian Adventist theologian, 'faithful reason is not a sacrifice of the intellect, but the integration of reason into faith'. In evolutionary psychology reason is unintegrated and alienated. Every 'thought' should be made captive and obedient to Christ (2 Cor 10:5). The human mind (reason or intellect) is therefore properly functional only if it is subject to the Lordship of Christ.

\section{Emotions and Christ: The renewed feelings}

Emotion is often scientifically defined as a complex state of feeling that results in physical and psychological changes, which influence thought and behaviour. Whether different emotions are caused by some physiological processes and reactions to certain events or cognitive processes by which we identify the reasons behind some arousals (Cherry 2012:1), they are always complex perceptions and reactions to radical changes in the human personality. In the recent debate on relationships between the psychology of emotions and the philosophy of mind, some experts claim that emotion also arises from the judgements and interpretations of the human brain based on past memory (that is, cognitive processes), and not only on external sensual perceptions and processes (Thagard 2010:1). In the past four decades contemporary evolutionary approaches have influenced and changed our anthropological understanding of the place and role of emotions in human life. According to Cosmides and Tooby (2000), emotions are certain adaptations that have arisen in response to adaptive problems. They mention the example of fear. Behavioural decisions and adaptations are based on the nature of potential threat, and over evolutionary time computational changes allowed the adaptive problem to be solved (2000).

In this research, the emotion of fear has been chosen as a case study in our attempt to integrate Psychology and Theology/ faith. Fear is an adaptive vital response to some physical or emotional threat, as we noted above. Some traumas nevertheless can trigger fears that are controlled with great difficulty. According to a recent observation (Albrecht 2012), there are five basic fears in every human being:

- Extinction - fear of annihilation, of ceasing to exist. This is a more fundamental way to express it than just calling it the 'fear of death'. The idea of no longer being arouses a primary existential anxiety in all normal humans. Consider that panicky feeling you get when you look over the edge of a high building.

- Mutilation - fear of losing any part of our precious bodily structure; the thought of having our body's boundaries invaded, or of losing the integrity of any organ, body part, or natural function. For example anxiety about animals, such as bugs, spiders, snakes, and other creepy things arises from fear of mutilation.

- Loss of autonomy - fear of being immobilized, paralyzed, restricted, enveloped, overwhelmed, entrapped, imprisoned, smothered, or controlled by circumstances. In a physical form, it's sometimes known as claustrophobia, but it also extends to social interactions and relationships.

- Separation - fear of abandonment, rejection, and loss of connectedness - of becoming a non-person - not wanted, respected, or valued by anyone else. The 'silent treatment', when imposed by a group, can have a devastating psychological effect on the targeted person.

- Ego-death - fear of humiliation, shame, or any other mechanism of profound self-disapproval that threatens the loss of integrity of the Self; fear of the shattering or disintegration of one's constructed sense of lovability, capability, and worthiness.

If one ponders upon each of these fears, it becomes clear that they belong to the general structure of being human. In the foundational structure of our personality we are fearful of death, harm to the body, loss of control, separation and loss of integrity. In terms of the 'Christian psychology' of fear, one can elaborate on the significance of the Lordship of Christ for this emotion. Firstly, Christ is the One who overcomes death and fear of death (Heb 2:14). Secondly, he is the protector of our bodily integrity. He is keeping us from harm in a general sense (Jr 29:11; Rm 13:10; 1 Jn 5:18; Rv 11:15). Thirdly, Christ is controlling our circumstances so that we should not fear the loss of autonomy. Fourthly, Christ's love is the most powerful means for overcoming fear of separation and abandonment 
(Rm 8:31-39). In him we are always valued and accepted. Finally, Christ's presence keeps us spiritually alive and contented even if our integrity and worthiness are threatened (Mt 28:20; Phlp 4:13). To use the language of evolutionary psychology, threat has been resolved, but not on the basis of adaptive processes or behavioural changes. The fear has been neutralised on the basis of openness to transcendence, namely the cosmic and sovereign God in Christ.

Of course, the renewed soul with its feelings is not impervious to external influences or causes and triggers of fear (or any other emotion), but Christ made a promise of overcoming the power of these causes (the world with its animosities). ${ }^{2}$ This is more than sufficient for a symmetric and holistic life without fear of harassment from our fears. The necessity for this transcendental spiritual dimension in our lives comes from the fact that we are often helpless in overcoming our fears, or even our fear of fears. This dimension of transformed feelings is a necessary component of a comprehensive theory of personality from a Christian point of view.

\section{Free will and Christ: The renewed power of choice}

If there is a free will, it means we can make our choices without their being determined by the physiology of our brain. We are not bound by the fatalistic structure of our personality or our circumstances, as some Greek and even modern philosophers have believed. According to the majority of philosophers and theologians, free will is factuality, since human beings are created to be free unless they are bound by the prison of their prejudices, tradition, system of beliefs, et cetera. The French existentialist JeanPaul Sartre claims that we are condemned to be free. His (Sartre 1993: part 4, ch 1) famous, 'Je suis condamné à être libre' [I am condemned to be free], means that we have to take risks in our lives to exist and make personal decisions without any objective determination arising from our tradition or background. For Sartre, freedom has become a burden of existence. Classical theory of personality would probably insert here the idea that we are indeed free but our choices are sometimes influenced even by the subconscious.

Volition therefore represents a psychological cognitive process by which an individual decides on a particular course of action. The automatisation of this process is called habit. Psychologically or philosophically, it has long been established that the human will is indeed really free. Therefore the existence of 'fate' as a controlling external power of our conscious decisions is denied.

Nevertheless, some individuals have a strong determination to take a certain course of action while others are 'weakwilled'. In this brief case study, let us take this concept and create a correlation with the concept of Christ's Lordship. According to the Holy Scripture, the weak-willed are those who really feel the need for the Lordship of Christ. 'Blessed are the poor in spirit' (Mt 5:3). Since people habitually choose the course of sin, Christ becomes the indispensable power who restrains the power of sin and redirects people's lives to a different course of action, namely faithful obedience. The freedom of the human being is indeed a burden only if it is exercised without any aid of the Spirit. The Spirit directs our lives towards a meaningful and purposeful goal - the kingdom of God. Salvation becomes thus all-inclusive since everyone is welcome in the kingdom of God, even those whose will is so weak that they need Christ for almost every decision in their lives. The Augustinian concept of predestination, though it affirms the paralysis of the will, is unwelcome here since it emphasises God's arbitrary approach to salvation.

Thus, the renewed and empowered faculty of free will becomes the experiential realisation of the integration of Psychology and Christian faith.

\section{Conscience and Christ: The converted heart}

Freud's 'superego' has been described as a reflection of moral values inherited by parents or the society. There are some recent debates on the relationship between this description of conscience and the classical Christian account of conscience, the two most influential functional models of conscience. One argument dismisses conscience as 'merely a part of Christian theology' while Lyons (2009), after examining both the classical Christian account of conscience and the Freudian account of conscience, argues for an account of conscience based on personal integrity. Contemporary Sociology offers an alternative through the investigation of 'morality's role in constructing social identities, and the importance of keeping these identities intact during times when our actions are inconsistent with them' (Sherman 2010). This theory is naturally based on the evolutionary model of human development. Contemporary Psychology and Sociology therefore affirm the existence of the integral human moral device for spot-checking right from wrong, namely conscience. What could then be the unique contribution of Christian faith in this regard? What is the exceptionality and distinctiveness of the Christian definition of the conscience?

Genesis 6:5 affirms: 'The LORD saw how great the wickedness of the human race had become on the earth, and that every inclination of the thoughts of the human heart was only evil all the time.' Antediluvians were engulfed by the power of sin to such an extent that the moral device of the conscience was entirely ineffective and fully distorted by $\sin$. Furthermore, the Scriptures affirm that the natural state of our conscience is not a fully reliable mechanism for distinguishing right from wrong. There are so many different expressions of conscience. On one side there is good conscience (Ac 23:1), pure conscience (1 Tm 3:9), clear conscience (Ac 24:16), and on the other side evil conscience (Heb 10:22), seared conscience (1 Tm 4:2), defiled (Tt 1:15) or weak conscience (1 Cor 8:7, 12). Limitation of space does not allow me to elaborate more on each of these states of human conscience (cf. unpublished lectures of Santrac 2011). 
Nevertheless, what is significant in this discussion is that the conscience alone is not reliable in determining moral good or evil. The Apostle Paul put it nicely in 1 Corinthians 4:4-5:

My conscience is clear, but that does not make me innocent. It is the Lord who judges me. Therefore, judge nothing before the appointed time; wait till the Lord comes. He will bring to light what is hidden in darkness and will expose the motives of men's hearts. At that time each will receive his praise from God. (NIV [author's own emphasis])

The Lordship of Christ in the conscience is what gives the conscience power and effectiveness as a moral device. The Lord is the ultimate judge of our moral reasoning, which is very often undependable because of its sinful nature. This is the basic difference between Christian faith and the scientific explorations of morality in Psychology. McBrien (1994) the renowned Catholic theologian, put it this way:

Conscience is the radical experience of ourselves as moral agents. Christian conscience is the radical experience of ourselves as new creatures in Christ, enlivened by the Holy Spirit. But since we never know ourselves completely (self-knowledge is something one works at; it is not ready made), decisions of conscience are necessarily incomplete and partial. And because our own circumstances are always historically, socially, and culturally defined, decisions of conscience are necessarily fallible and subject to correction and change. (p. 969)

Morality is therefore never neutral. Conscience is never empty. The content (and correction) of our conscience comes from the Word of God, and the power to exercise it properly comes from the Spirit of God. As Luther (1521) famously states:

Unless I am convinced by proofs from Scriptures or by plain and clear reasons and arguments, I can and will not retract, for it is neither safe nor wise to do anything against conscience. Here I stand. I can do no other. God help me. Amen.

The Lordship of Christ calls for the transformation of our moral mechanisms by the content of the Word of God and the regeneration of the conscience by the power of the Spirit of Christ's Lordship.

Let me now explore the final element in my integration of the faculties of human personality and the Christian awareness of Christ's Lordship.

\section{Faith or spirituality and Christ: The transformed spirituality}

Modern psychologists, at least in the United States, identify the need, both in theory and practice, for correlation between human spirituality and the scientific tools of Psychology. The following serves as examples.

In 1990 Edward P. Shafranske (PhD of Pepperdine University) and H. Newton Maloney (PhD of Fuller Theological Seminary) surveyed 409 members of the American Psychological Association about their approach toward religion and Psychology. Nearly all respondents said they have assessed patients' religious backgrounds; $57 \%$ have used religious language or concepts with patients; $36 \%$ have recommended participation in religion; $32 \%$ have recommended religious or spiritual books; $24 \%$ have prayed privately for a patient; and 7\% even prayed with a client (Elkins 2012:1).

In today's religious or spiritualistic world, psychologists cannot avoid speaking about the integration of Christian faith (or faith in general) with the scientific theories and practices of Psychology. On what philosophical ground is the integration between the spiritual faculty of human nature and the concept of the Lordship of Christ possible? Let me use the following debate, taken from a recent blog of Richmond (2012), as a starting point of discussion on this integration:

In his masterful play, Man and Superman, George Bernard Shaw turned the classical images of heaven and hell upside down. He described hell as a place of complete satisfaction, where all desires are freely fulfilled. Personal responsibility had no place in hell. It did in heaven, though, a place for the 'masters of reality' - and, curiously enough, the place where souls were free to go when they finally got sick of hell. This is a provocative metaphor. Being a metaphor, though, it is not to be taken literally in a metaphysical sense. But it is a good metaphor for how we live our life in this world, because this concept of 'a hell that you can leave when you get sick of it' aptly describes psychological change as well. Many people cling to their own psychological 'hell', no matter how painful it may be, because the discipline of health is even more fearful. But eventually, if they catch only a glimpse of sorrow for the mess they're in, they can get sick of it all and decide to cross over to 'reality'. Therefore, though an atheist, not a theologian, Shaw nevertheless made a brilliant discovery: a spiritual life is also a practical life. Yet such practicality does not depend on knowledge so much as understanding.

Too many persons today, however, preoccupy themselves with knowledge, whether it be intellectual or carnal, and in doing so they sidestep the concept of understanding. Why? Because understanding involves 'standing under something', and that something is the 'law' - not the local penal code, but the psychological law of lack and limitation that holds the agony of being itself as it stands on the brink of redemption through divine love. All the pages of knowledge flap uselessly in the swirling gusts that blow along that ridge.

Accordingly, spiritual journey is based on the quest for meaning against the agony of the self-limitations of our being. The full understanding (vs knowledge) of the transcendent divine love of Christ gives fullness of meaning (spiritual meaning) to our lives. The spiritual substratum of our life is this understanding of redeeming divine love that transforms itself into a meaningful practical life of service to our neighbour and humanity. This aspect of spirituality has been forgotten in the scientific exploration of spirituality as a faculty of the human soul. Renewed spirituality is preoccupied with the Lordship of Christ. There is only one foundation for the integration of Psychology and the human faculty of spirituality: the quest for ultimate meaning is rewarded by the experience of the divine love and Lordship of Christ. 


\section{Reality and purpose of an integrative paradigm}

I have to admit that attempts of this kind to integrate psychological theories of human faculties and Christian theory or revelation of the sovereignty of Christ have been found wanting. In the introduction of this article I have clearly expressed the types of risk in this regard. For example, Harry A. van Belle (n.d.) in his article, 'Structure and direction: Recounting the presence of God in therapeutic relation', rejects all attempts for integration between Psychology and Christian faith on several grounds. He (n.d.) quotes Steve Bouma-Prediger:

Does one integrate psychology with faith, or the bible, or revelation, or theology, or a Christian world view, or Christian belief, or Christianity, or religion? Does one integrate theology (or faith, Christianity, etc.) with psychology, or science, or therapy, or counseling? Does one integrate theory with practice, or faith with practice, or faith with learning or faith with vocation, or religious experience with therapy? In other words, what precisely are the relata in the integrative relationship?

Furthermore, Bouma-Prediger (1990) asks:

\begin{abstract}
... what exactly does the term 'integrate' mean? Does it mean merely to relate, or does it mean, more specifically, to combine, to harmonize, to unify ... what integrates with what and what is the precise character of that integrative relationship? (p. 23)
\end{abstract}

These valid questions express the confusion over the integrating process. Let me try to reply. In my attempt to integrate psychological perspectives on human personality and the Christian faith I assert that the primary goal of this article is to integrate theory of personality with a theoretical Christian perspective based primarily on the Holy Scriptures. The purpose of this integration is to demonstrate the superiority of a holistic Christian theory of personality to compartmentalised and disintegrated psychological theories of personality. For Christians, the reference point of this Christian theory of personality is Christ, as he unifies the faculties of the soul into a holistic perception of human nature created in God's image.

Van Belle (n.d.) believes that there is an alternative to all types of integrative paradigms, namely his structure and direction paradigm (structure as the norm giving activity of God in therapy and direction as human response to this structure). Nevertheless, his main concern is therapeutic purpose, which is not my primary intention, so I will not elaborate more on this alternative approach.

\section{Conclusion}

This article addresses the pertinent question of some new possible vistas of integration of Psychology, in its scientific and theoretical approach, and Christian faith or Theology. Since some recent scholarly debates distrust attempts to integrate these two academic and spiritual disciplines through the traditional method of searching for philosophical assumptions, the article ventures to create a possible new mode of integration, based on the correlation between human faculties (intellect, emotions, free will, conscience and spirituality) and the biblical and theological conceptualisation of the Lordship of Christ.

Every faculty of the human 'soul' has its proper holistic function only if it is renewed and transformed by the Spirit of Christ. The plea for wholeness, so often undervalued by the contemporary psychology of compartmentalisation of human personality, can be fulfilled by the intellectual and spiritual endeavour of joining up every faculty of human personality with an indispensable transcendental experience of the Lordship of Christ that gives ultimate meaning to the nature and function of human faculties. After all, only the renewed imago Dei makes the human being wholly human.

I believe that perspectives on Psychology and Christian spirituality may be integrated within the context of a debate about theories of personality. Discussion about the theoretical basis of this debate may open some possibilities for other forms of integrative paradigms. In fact, this is just the beginning of scholarly work on this momentous topic. However, one thing is certain: there is no promising future for the project of Christian Psychology without serious academic endeavour to find new ways of integrating the scientific accomplishments of Psychology and its implications with the Christian worldview.

\section{Acknowledgements Competing interests}

The author declares that he has no financial or personal relationships which may have inappropriately influenced him in writing this article.

\section{References}

Albrecht, K., 2012, 'The (only) five fears we all share', viewed 1 April 2015, from https://www.psychologytoday.com/blog/brainsnacks/201203/the-only-5-fearswe-all-share

Bouma-Prediger, S., 1990, 'The task of integration: A modest proposal', Journal of Psychology and Theology 18(1), 21-31.

Buss, D. (ed.), 2011, Evolutionary psychology, Pearson, Cambridge.

Chambers, O., 2012, 'My utmost for his Highest', viewed 8 November 2012, from http://utmost.org/

Cherry, K., 2012, 'Theories of emotion', viewed 8 November 2012, from http:// psychology.about.com/od/psychologytopics/a/theories-of-emotion.htm

Cosmides, L. \& Tooby, J. 2000, 'Evolutionary psychology and the emotions', in M. Lewis \& J.M. Haviland-Jones (eds.), Handbook of emotions, 2nd edn., pp. 114-137, Guilford Press, Guilford, CT.

Elkins, D.N., 2012, 'Spirituality', viewed 8 November 2012, from http://www. psychologytoday.com/articles/199909/spirituality

Evans, S.C., 2012, 'Doing psychology as a Christian: A plea for wholeness', Journal of Psychology and Theology 40(1), 32-36.

Hasel, F., 1993, 'Theology and the role of reason', Journal of Adventist Theological Society 4(2), 172-198.

James, W., 2002, The varieties of religious experiences: A study in human nature, 2nd edn., The Modern Library, New York.

Luther, M., 1521, 'Excerpts from his account of the confrontation at the Diet of Worms, 18 April 1521', view 1 March 2015, from http://www-personal.ksu. edu/ Iyman/english233/Luther-Diet_of_Worms.htm

Lyons, W., 2009, 'Conscience - An essay in moral psychology', Philosophy 84(4), 477-494. http://dx.doi.org/10.1017/S0031819109990076

McBrien, R.P., 1994, Catholicism, Harper One \& Harper Collins, New York.

Richmond, R.L., 2012, 'Spirituality and psychology', viewed 1 March 2015, from http://www.guidetopsychology.com/spirit.htm 
Roberts, R.C., 2012, 'The idea of Christian Psychology', Journal of Psychology and Theology 40(1), 37-40.

Santrac, A.S., 2011, “"The mind of Christ": A philosophical foundation for a program in Christian Psychology', Mind of Christ Conference, University of the Southern Caribbean, Trinidad, 8-10th February.

Sartre, J.-P., 1993, Being and nothingness, 2nd edn., Washington Square Press, Washington, D.C.

Sherman, J., 2010, 'Book review: Moral selves, evil selves: The Social Psychology of conscience', Social Forces 89(2), 712. http://dx.doi.org/10.1353/sof.2010.0093

Shults, F.L., 2012, 'Dis-integrating psychology and theology', Journal of Psychology and Theology 40(1), 21-25.
Stevenson, L. \& Haberman, D.L., 1998, Ten theories of human nature, Oxford University Press, Oxford.

Thagard, P., 2010, 'Theories of emotions', viewed 8 November 2012, from http:// www.psychologytoday.com/blog/hot-thought/201004/what-are-emotions

Tjeltveit, A.C., 2012, 'Lost opportunities, partial successes, and key questions: Some historical lessons', Journal of Psychology and Theology 40(1), 16-20.

Van Belle, H.A., n.d., 'Structure and direction: Recounting the presence of God in the therapeutic relation', viewed 6 May 2015, from http://www.kingsu.ca/public/ download/documents/2018

Watts, F., 2012, 'Doing theology in dialogue with psychology', Journal of Psychology and Theology 40(1), 45-50. 